\title{
Comparative Study of Scoparone Accumulation in Various Citrus Species after Inoculation with Gray Mold
}

\author{
Takeshi Kuniga* and Ryoji Matsumoto** \\ Department of Citrus Research, Kuchinotsu, National Institute of Fruit Tree Science, Kuchinotsu, Nagasaki 859-2501, Japan
}

\begin{abstract}
Gray mold (Botrytis cinerea Persoon) induced the accumulation of scoparone (6,7-dimethoxycoumarin) in the flavedo of fruit in all citrus species used in this study. The time-course of the accumulation of this compound was species dependent. In the fruit of 'Kiyomi' and Meiwa kumquat, scoparone accumulated gradually over several days after inoculation. No accumulation occurred in the non-inoculated citrus fruit. In several citrus species, including Tankan, 'Seminole', and 'Ellendale', Scoparone concentration increased up to 4 days after treatment. In 'Murcott', 'Triumph', and Yuzu, the maximum concentration was observed within 7 days of treatment. On the other hand, in 'Imamura-unshu', 'Kawano Natsudaidai', Ponkan, 'Morita Navel', Kinukawa, 'Eureka' lemon, kumquats, calamondin, and citrangequat, the increase in scoparone was much lower. These results suggest that scoparone is a phytoalexin induced by gray mold, accumulating in a broad range of citrus species.
\end{abstract}

Key Words: Citrus, Phytoalexin, Scoparone, Ultraviolet (UV).

\section{Introduction}

A number of constitutive and induced antifungal compounds have been identified from the reproductive organs of Citrus species. Scoparone is considered to be a citrus phytoalexin. A phytoalexin is defined as a lowmolecular-weight secondary metabolite that is formed de novo as a result of physical, chemical, or biological stress. It resists or suppresses the activity of fungal or bacterial disease. Its rate of production/accumulation depends on the host and pathogen genotypes (Purkayastha, 1994).

Scoparone was isolated from the bark of citrus trunks and branches following inoculation with the fungus Phytophthora citrophthora (Afek and Stejnberg, 1988; Afek et al., 1986). The concentration of scoparone was high and increased very rapidly within $24 \mathrm{~h}$ after inoculation in the resistant species; however, in the susceptible species, concentrations did not increase. In the non-inoculated control, the concentration of scoparone was very low (about $12-18 \mu \mathrm{g} \cdot \mathrm{g}^{-1} \mathrm{FW}$ ), and no effect on scoparone production was observed (Afek and Sztejnberg, 1994).

Received; June 20, 2005. Accepted; January 24, 2006.

A part of this paper was presented at the 2003 Autumn meeting of the Japanese Society for Horticultural Science.

* Corresponding author (E-mail: kuchino@affrc.go.jp).

* Present address: Department of Citrus Research, Okitsu, National Institute of Fruit Tree Science, Okitsunaka-cho, Shizuoka 4240292, Japan.

** Present address: Faculty of Agriculture, Saga University.
Postharvest losses of fruits and vegetables are usually heavy. Such losses are mainly due to pathogenic fungi, which primarily infect the host through wounds made during the harvesting, handling, and processing of the fruit. The fungus Botrytis cinerea (gray mold) is a ubiquitous pathogen with a broad range of hosts. It causes considerable damage to many crops of high economic value, including citrus, grape, peach, and apple. Both the quantity and quality of produce are affected. The use of antifungal phytoalexins is expected to improve the safety and volume of citrus production.

In this study, we investigated the response of citrus fruit to gray mold inoculation, which relates to the accumulation of scoparone in the flavedo tissue and resistance to decay in various citrus species.

\section{Materials and Methods}

1. Changes in the concentration of scoparone in inoculated citrus fruits

Fruits of the 'Kiyomi' and Meiwa kumquat were obtained directly from orchards in the middle of March, 2000, from the National Institute of Fruit Tree Science, Kuchinotsu, Nagasaki Prefecture. The skins of these fruits were washed with a $70 \%$ Et-OH solution and distilled water before inoculation with gray mold.

Gray mold (No. 2202) was obtained from the Laboratory of Plant Pathology at Kobe University and cultured on a potato dextrose agar (PDA) medium at a temperature of $25^{\circ} \mathrm{C}$ under continuous radiation from a near-ultraviolet (NUV) fluorescent lamp (FL30BLB, 3.6 $\times 10^{6} \mathrm{~W} \cdot \mathrm{cm}^{-2}$, Toshiba Co., Ltd., Japan). Sporulation occurred within a week. A suspension was prepared by 
flooding 7-day-old sporulated culture plates with sterilized water and dislodging the conidia by means of a funnel and cotton. The spore concentration was adjusted to $5 \times 10^{5}$ spores $/ \mathrm{mL}$ with a haemacytometer. This concentration was determined to cause decay. Inoculation was performed according to the methods of Rodov et al. (1994) and Afek et al. (1999), with some modifications.

Either on the day of harvest or one day later, gray mold was inoculated by causing a wound to the flavedo with a depth of $1 \mathrm{~mm}$ and diameter of $3 \mathrm{~cm}$ and injecting the spore suspension through it. In the control trials, sterilized water was used instead of an antagonist and/or pathogen spore suspension.

Inoculated and control fruits were incubated in the dark at $25^{\circ} \mathrm{C}, 100 \% \mathrm{RH}$. For seven days on a daily basis, the flavedo of the wounded area $(1 \mathrm{~mm}$ depth and $3 \mathrm{~cm}$ diameter) was excised using knives, and five replications were collected. The samples were stored at $-20^{\circ} \mathrm{C}$.

The methods used for phytoalexin measurement were those of Kuniga et al. (2005), as modified by Kim et al. (1991). The samples were extracted with an $80 \% \mathrm{Et}-\mathrm{OH}$ solution, the solution was centrifuged and evaporated, and then the aquaeous phase was partitioned with $\mathrm{CH}_{2} \mathrm{Cl}_{2}$. The $\mathrm{CH}_{2} \mathrm{Cl}_{2}$ fraction was dried and dissolved with $4 \mathrm{~mL}$ of $30 \% \mathrm{Me}-\mathrm{OH}$. Two hundred micro liters of filtered solution was injected into the HPLC, and analysis was carried out by a JASCO LC 800 system equipped with a $\mathrm{C}_{18}$ column (Inertsil ODS2 $4.6 \times$ $150 \mathrm{~mm}$, GL Science Inc., Japan). The gradient used was $\mathrm{Me}-\mathrm{OH} 20-70 \%$ for $26 \mathrm{~min}$, and the flow rate was $1.2 \mathrm{~mL} \cdot \mathrm{min}^{-1}$ at $40^{\circ} \mathrm{C}$. Scoparone was detected using a fluorescence spectrophotometer (821-F Intelligent UV/ VIS Detector, JASCO, Japan). The fluorescence was monitored with excitation at $330 \mathrm{~nm}$ and emission at $400 \mathrm{~nm}$. The retention time of the compound was $20.6 \mathrm{~min}$. The scoparone concentration was calculated as $\mu \mathrm{g}$ per $\mathrm{gFW}$.

2. Scoparone synthesis in various citrus species in response to inoculation with gray mold

Citrus fruits shown in Table 1 were obtained in late December, 2001, from the National Institute of Fruit Tree Science, Kuchinotsu. The time of harvest was

Table 1. Citrus species and cultivars used in the experiment.

\begin{tabular}{|c|c|}
\hline Cultivar or Common name & Scientific name (parents) \\
\hline 'Imamura-unshu' & Citrus unshiu Marc. \\
\hline Ponkan & C. reticulata Blanco \\
\hline Kunenbo & C. nobilis Lour. \\
\hline 'Fukuhara Orange' & C. sinensis Osbeck forma Fukuhara \\
\hline 'Morita Navel' & C. sinensis Osbeck var. brasiliensis Tanaka \\
\hline Kaiseito (Zadaidai) & C. aurantium L. var. Cyathifera Y. Tanaka \\
\hline ‘Hareyaka’ (Hybrid) & $($ C. nobilis $\times C$. deliciosa Tenore $) \times C$. reticulata ('Encore' $\times$ 'Nakano No. 3 Ponkan') \\
\hline 'Tsunokaori' (Hybrid) & $($ C. unshiu $\times$ C. sinensis $) \times C$. unshiu $($ 'Kiyomi' $\times$ 'Okitsu-wase') \\
\hline ‘Kiyomi’ (Hybrid) & C. unshiu $\times$ C. sinensis ('Miyagawa-wase' $\times$ 'Trovita') \\
\hline ‘Shiranuhi’ (Hybrid) & $($ C. unshiu $\times$ C. sinensis $) \times$ C. reticulata ('Kiyomi' $\times$ 'Nakano No. 3 Ponkan') \\
\hline 'Ellendale’ (Hybrid) & C. reticulata $\times$ C. sinensis (Unknown origin) \\
\hline 'Murcott' (Hybrid) & C. reticulata $\times$ C. sinensis (Unknown origin) \\
\hline Tankan & C. tankan Hayata \\
\hline ‘Miyauchi Iyokan' (Iyo) & C. iyo Hort. ex Tanaka \\
\hline ‘Seminole’ (Hybrid) & C. $\times$ tangero J. W. Ingram \& H. E. Moore \\
\hline 'Kawano Natsudaidai' & C. natsudaidai Hayata \\
\hline Kinukawa & C. glaberrima Hort. ex Tanaka \\
\hline 'Sweet Spring' (Hybrid) & C. unshiu Marc. $\times$ C. hassaku Hort. ex Tanaka ('Ueda-unshu' $\times$ Hassaku) \\
\hline Hassaku & C. hassaku Hort. ex Tanaka \\
\hline Hyuganatsu & C. tamurana Hort. ex Tanaka \\
\hline Naruto & C. medioglobosa Hort. ex Tanaka \\
\hline 'Triumph' (seedling) & C. paradisi Macf. forma Triumph \\
\hline 'Eureka' lemon & C. limon Burm. forma Eureka \\
\hline Yuzu (Seedless) & C. junos Sieb. ex Tanaka \\
\hline Yuzu & C. junos Sieb. ex Tanaka \\
\hline Sweet lime & C. limettioides Tanaka \\
\hline Citrangequat & Fortunella spp. $\times($ C. sinensis $\times$ Poncirus trifoliata $)$ (Unknown origin) \\
\hline Calamondin & C. madurensis Lour. \\
\hline Naga (Oval) kumquat & F. margarita Swingle \\
\hline Meiwa kumquat & F. crassifolia Swingle \\
\hline
\end{tabular}


determined to obtain as many citrus species as possible. Inoculation and scoparone measurement were performed using the same methods as described in "1. Changes in the concentration of scoparone in inoculated citrus fruits". Five replicated samples were collected at the time of application and 4 and 7 days after treatment. In calamondin and kumquats, ten replications were collected.

To study the correlation between scoparone synthesis and the decay rate, the decay rate of inoculated fruit resulting from gray mold was measured in the replications at 4 and 7 days after treatment. In calamondin and kumquats, the decay rate was measured in 20 replications. The decay rate was calculated as a percentage.

\section{Results}

1. Changes in the concentration of scoparone in inoculated citrus fruits

The scoparone concentration in 'Kiyomi' and Meiwa kumquat flavedo increased following inoculation with gray mold. In Meiwa kumquat, the concentration of scoparone was $20 \mu \mathrm{g} \cdot \mathrm{g}^{-1} \mathrm{FW}$ at 4 days after treatment. In 'Kiyomi', it was $175 \mu \mathrm{g} \cdot \mathrm{g}^{-1} \mathrm{FW}$ at 5 days after treatment. After reaching its maximum, the concentration of scoparone began to decline and was $60 \mu \mathrm{g} \cdot \mathrm{g}^{-1} \mathrm{FW}$ at

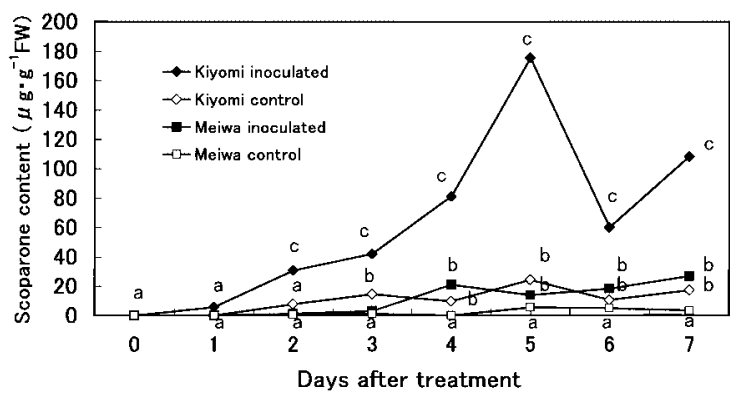

Fig. 1. Changes of scoparone contents in citrus fruit peel after inoculation treatments with Botrytis cinerea. Significant differences are indicated by different letters within each time period according to Tukey's Multiple Comparison test $(P=0.05)$.

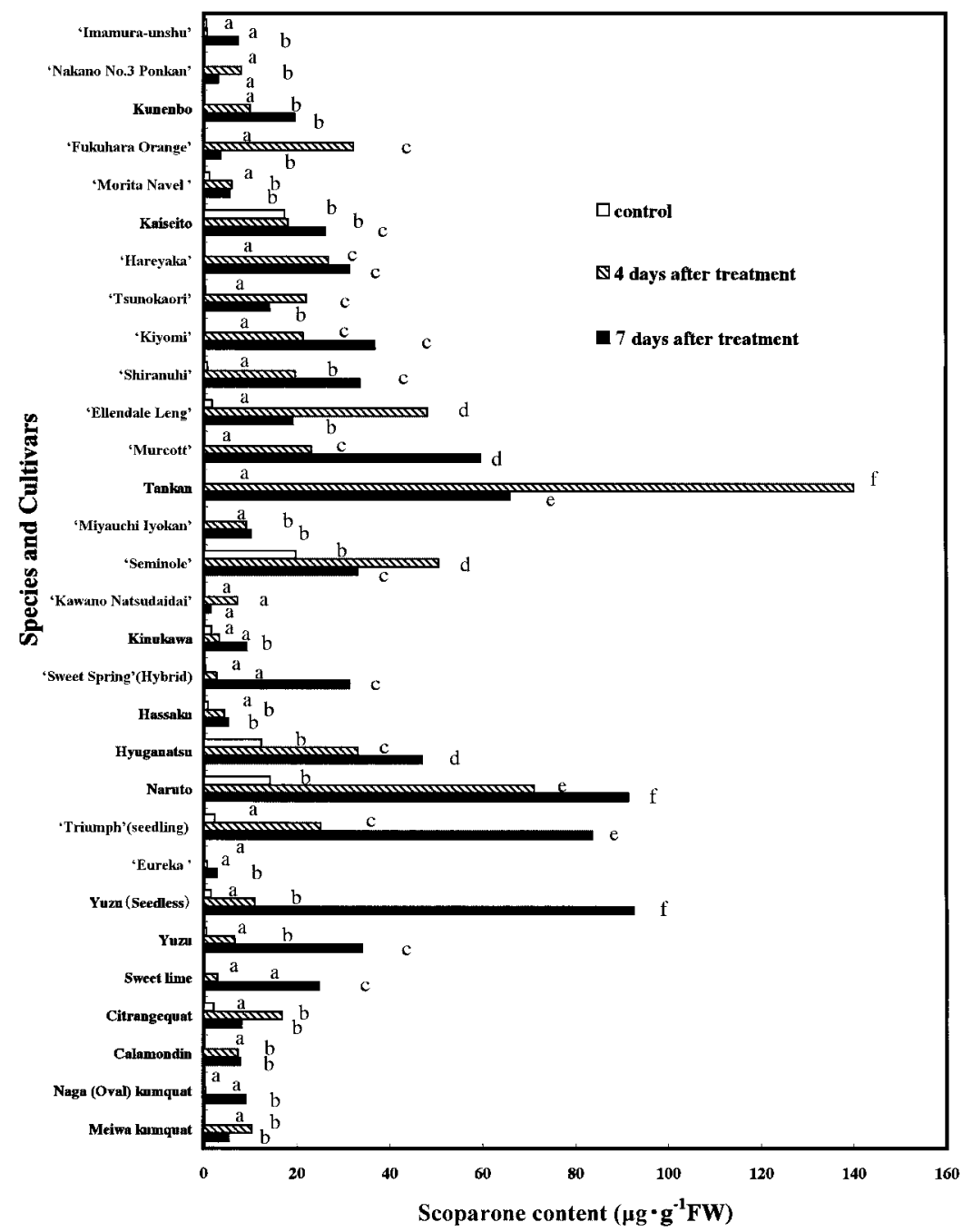

Fig. 2. Scoparone content of the inoculated citrus fruits. Significant differences are indicated by different letters according to Tukey's Multiple Comparison test $(P=0.05)$. 


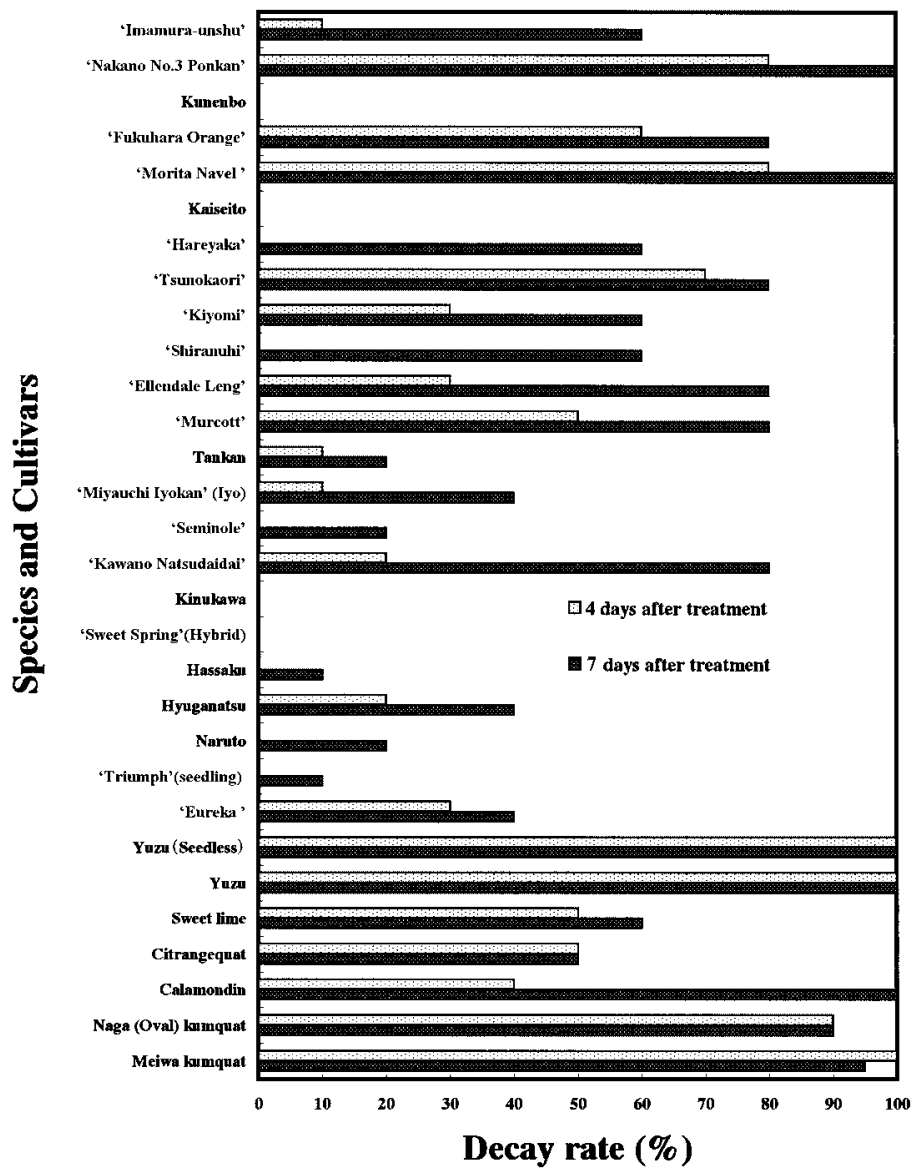

Fig. 3. Decay rate of the inoculated citrus fruits.

6 days after inoculation. In Meiwa kumquat, the concentration did not decrease and reached a maximum of $26.9 \mu \mathrm{g} \cdot \mathrm{g}^{-1} \mathrm{FW}$ at 7 days after treatment at the end of the analysis period. Control fruits of both species showed little or no changes in scoparone concentration over the same period. The concentration was $0-21 \mu \mathrm{g} \cdot \mathrm{g}^{-1} \mathrm{FW}$ and $0-5 \mu \mathrm{g} \cdot \mathrm{g}^{-1} \mathrm{FW}$ in 'Kiyomi' and Meiwa, respectively (Fig. 1). These values were much lower those in the inoculated flavedo.

\section{Scoparone synthesis in various citrus species in response to inoculation with gray mold}

The magnitude of the response to inoculation in the flavedo of fruits in terms of scoparone accumulation was cultivar-dependent (Fig. 2). The highest accumulation of scoparone was recorded in Tankan at 4 days after inoculation. In addition, in 'Ellendale', 'Fukuhara Orange', and 'Seminole', the maximum concentration of scoparone was detected after 4 days. On the other hand, 7 days after treatment, 19 of the 30 species involved in this experiment reached their peak concentrations of the compound. In Yuzu, 'Murcott', and 'Triumph', the concentration of scoparone increased until day 7 after treatment. The increase in scoparone was much less in the following species: 'Imamura-unshu', 'Kawano Natsudaidai', Ponkan, 'Morita Navel', Kinukawa,
'Eureka' lemon, kumquats, calamondin, and citrangequat.

Within four days after treatment, the development of gray mold decay varied according to the species. Ponkan, 'Tsunokaori', 'Morita Nanel', Yuzu, and kumquats were found to be highly susceptible to decay. On the other hand, 'Imamura-unshu', Kunenbo, 'Hareyaka', 'Shiranuhi', Tankan, 'Kaiseito', Iyo, 'Seminole', Kinukawa, 'Sweet Spring', Hassaku 'Naruto', and 'Triumph' were resistant. However, the decay rate increased in 'Imamura-unshu' and 'Hareyaka' 7 days after treatment. Kunenbo, 'Kaiseito', Kinukawa, and 'Sweet Spring' did not show any signs of decay. Hyuganatsu, 'Eureka' lemon, Sweet Lime, and citrengequat showed intermediate signs (Fig. 3). Those citrus species, with a decay percentage of less than $20 \%$ at 4 days after treatment, produced nearly $10 \mu \mathrm{g} \cdot \mathrm{g}^{-1} \mathrm{FW}$ of scoparone during the same period. It is noteworthy that species such as Iyo, Kunenbo, 'Sweet Spring', and Hassaku, which produced less than $10 \mu \mathrm{g} \cdot \mathrm{g}^{-1} \mathrm{FW}$ of scoparone, possess harder peel than other citrus.

\section{Discussion}

This study demonstrated the induction of scoparone accumulation in the flavedo tissue of citrus fruits after inoculation with $B$. cinerea. Several studies have 
reported that scoparone was involved in the defense mechanism of Citrus spp. against pathogens such as Diaporthe citri (Arimoto et al., 1986), Phytophthora citrophthora (Afek and Sztejnberg, 1988), Phytophthora gummosis (Afek et al., 1986), and Penicillium digitatum (Rodov et al., 1992).

Arimoto et al. (1986) and Afek and Sztejnberg (1988) showed that scoparone was only slightly detected or absent in healthy organs. In this study, scoparone at very low levels was also detected in healthy fruit that was not stressed and was induced in citrus species after inoculation with gray mold. However, there were some differences in the maximum content and accumulation in the flavedo tissue after treatment. The changes in scoparone concentration in 'Kiyomi' and Meiwa kumquat which were harvested in March represented a typical example of such a case (Fig. 1). 'Kiyomi' produced more scoparone than another species, and the amount increased rapidly.

In this study, scoparone increased in all species. There were differences in the time to reach the peak concentration of the compound. In 19 out of 30 species, the peak occurred at 7 days after inoculation, and, in the remaining 11 , the maximum was reached at 4 days after treatment. These results suggest that scoparone is a phytoalexin against $B$. cinerea, and changes in scoparone concentration are citrus species-specific after inoculation with gray mold. The differences in scoparone concentration appeared to be related to maturity, the quantity of the substrate, synthetase, catalase, and other factors.

D'hallewin et al. (1999) reported that fruit age affected scoparone that accumulated as a result of UV stimuli. The induction of scoparone synthesis in 'Kiyomi' was affected by the harvest dates in our results. In December, the scoparone concentration was $36.8 \mu \mathrm{g} \cdot \mathrm{g}^{-1} \mathrm{FW}$ at 7 days after inoculation. However, in March, the concentration was $175 \mu \mathrm{g} \cdot \mathrm{g}^{-1} \mathrm{FW}$ at 5 days after treatment. These results suggest that scoparone accumulation was affected by the age of the fruit.

Afek and Sztejnberg (1988) showed that scoparone accumulation was associated with resistance of citrus to $P$. citrophthora. In that study, scoparone was induced in both resistant and susceptible fruits, but the concentration was higher and increased more rapidly in resistant fruits. Twenty-four hours after inoculation, the concentration of scoparone in the bark of the resistant species was about three times higher than that in the bark of susceptible species. The high concentration of scoparone within the first $24-48 \mathrm{~h}$ is critical to inhibit the advance of the pathogen in vivo (Afek and Sztejnberg, 1994).

There was no correlation ( 4 and 7 days after) between the scoparone concentration and decay rate $(r=-0.21$ and -0.26). Some of the citrus species (Iyo, Kunenbo, Tankan, etc.), with a decay percentage of less than $20 \%$ at 4 days after treatment, produced more than $10 \mu \mathrm{g}$. $\mathrm{g}^{-1} \mathrm{FW}$ of scoparone during the same period. These results suggest that decay, especially at the initial stage of infection, is related to the accumulation of scoparone and peel hardness in some cases. Therefore, gray mold decay could be prevented by a pre-treatment that results in the production of a certain amount of scoparone.

However, the decay rate increased in 'Fukuhara Orange' 4 days after treatment in spite of the accumulation of scoparone. Therefore, there must be some different mechanism by which decay spreads in 'Fukuhara Orange'.

An understanding of the mechanism of synthesis of phytoalexin in citrus can help to explain the pattern of resistance to fungi. Further approaches are needed to analyze scoparone synthesis.

\section{Acknowledgements}

We thank Drs. Shigeto Tominaga and Masashi Yamamoto of Kagoshima University, Yoshinori Hasegawa of the National Institute of Fruit Tree Science and Prof. J. L. Guardiola of Universidad Politécnica de Valencia for their valuable advice.

In addition, we are also grateful to Ms. Sachiko Mori, Ms. Yoko Makita and Mr. Takanori Yamamoto for assisting with this study.

\section{Literature Cited}

Afek, U. and A. Sztejnberg. 1988. Accumulation of scoparone, a phytoalexin associated with resistance of citrus to Phytophthora citrophthora. Phytopathology 78: 16781682.

Afek, U. and A. Szteinberg. 1994. Scoparone (6,7dimethoxycoumarin), a Citrus phytoalexin involved in resistance to pathogens. p. 262-286. In: M. Dniel and R. P. Purkayastha (eds.). Handbook of phytoalexin metabolism and action. Marcel Dekker Inc. New York, Basel, Hong Kong.

Afek, U., A. Sztejnberg and S. Carmely. 1986. 6,7dimethoxycoumarin, a citrus phytoalexin conferring resistance against Phytophthora gummosis. Phytochemistry 25: $1855-1856$.

Afek, U., J. Orenstein, S. Carmeli, V. Rodov and M. B. Joseph. 1999. Umbeliferone, a phytoalexin associated with resistance of immature Marsh grapefruit to Penicillium digitatum. Phytochemistry 50: 1129-1132.

Arimoto, Y., Y. Homma and T. Ohsawa. 1986. Studies on citrus melanose and citrus stem-end rot by Diaporthe citri (Faw.) Wolf. Part 5. Identification of a phytoalexin in melanose spot. Ann. Phytopath. Soc. Japan. 52: 620-625.

D'hallewin, G., M. Scirra and E. Manueddu. 1999. Scoparone and scopoletin accumulation and ultraviolet-C induced resistance to postharvest decay in oranges as influenced by harvest date. J. Amer. Soc. Hort. Sci. 124: 702-707.

Kim, J. J., S. B.-Yehoshua, B. Shapiro, Y. Henis and S. Carmeli. 1991. Accumulation of scoparone in heat-treated lemon fruit inoculated with Penicillium digitatum Sacc. Plant Physiol. 97: 880-885. 
Kuniga, T., Y. Matsuo, T. Tsumura, K. Kojima and R. Matsumoto. 2005. Production of phytoalexin, scoparone in citrus species following treatment with UV radiation. Hort. Res. (Japan) 4: 99-103 (In Japanese with English summery).

Purkayastha, R. P. 1994. Progress in phytoalexin research during the past 50 years. p. 1-39. In: M. Daniel and R. P. Purkayastha (eds.). Handbook of phytoalexin methabolism and action. Marcel Dekker Inc. New York, Basel,

\section{Hong Kong.}

Rodov, V., S. B. Yehoshua, J. J. Kim, B. Shapiro and Y. Ittah. 1992. Ultraviolet illumination induces scoparone production in kumquat and orange fruit and improves decay resistance. J. Amer. Soc. Hort. Sci. 117: 788-792.

Rodov, V., S. B. Yehoshua and D. Fang. 1994. Accumulation of phytoalexins scoparone and scopoletin in citrus fruits subjected to various postharvest treatments. Acta Hort. 381: 517-523.

\title{
灰色かび病菌感染によるカンキッ類のスコパロン蓄積量の差異
}

\author{
國賀 武*・松本亮司**
}

独立行政法人農業・生物系特定産業技術研究機構果樹研究所カンキッ研究部口之津 859-2501 長崎県南高来郡口之津町乙

病原菌の感染によりカンキツ類で生成するファイトア レキシンであるスコパロンの灰色かび病菌接種よる蓄積 量の経時変化および品種間差異について検討した。灰色 かび病菌の分生胞子を果皮に接種したことで“清見”と ネイハキンカンのフラベド中のスコパロンの蓄積量は数 日で増加した。 これに対して接種をしなかった場合，ス コパロン蓄積量は試験期間中増加しなかった。 また， 夕 ンカン, ‘セミノール’, ‘エレンデール’などでスコパロ ンの蓄積量が多く, その量は接種 4 日後で最大值に達し た. ‘マーコット’，“トライアンフ’，ユズ等でも 7 日後 に最大值を示した。 これに対し，“川野なつだいだい’，
‘ユーレカ’レモン，シキキッ，“今村温州’などでは蓄 積量が少なかった．以上の結果からスコパロンは灰色か び病に対するカンキツ類のファイトアレキシンであり, その蓄積量に種間または品種間で差異があることが明ら かになった。

* 現在 : 独立行政法人農業・生物系特定技術研究機構 果樹研究所カンキツ研究部興津 424-0292 静岡市 清水区興津中町.

** 現在 : 佐賀大学農学部. 